\title{
Staphylococcus epidermidis in Urine Is Not Always Benign: A Case Report of Pyelonephritis in a Child
}

\author{
Valentina Lozano, BS, Gabriela Fernandez, BS, Patricia L. Spencer, MD, MBA, MPH, \\ Susan L. Taylor, PharmD, and Robert Hatch, MD, MPH
}

Purpose: Staphylococcus epidermidis in urine cultures from previously healthy children is usually considered to be a contaminant. The goal of this study was to identify cases in which $\boldsymbol{S}$. epidermidis was an infectious cause of urinary tract infection (UTI) in children.

Methods: A literature search identified 7 cases, 6 of which were previously published and 1 which was unpublished, described herein.

Results: S. epidermidis was identified as the causative organism of UTIs in children with underlying urinary tract abnormalities.

Conclusion: UTIs caused by $S$. epidermidis in a previously healthy child should not be disregarded as a contaminant and further workup for urinary tract abnormality is indicated. ( $\mathrm{J}$ Am Board Fam Med 2015;28:151-153.)

Keywords: Staphylococcus epidermidis, Urinary Tract Infections, Vesicoureteral Reflux

In healthy children, urinary tract infections (UTIs) are usually caused by Gram-negative organisms (mainly Escherichia coli) and certain Gram-positive organisms such as Staphylococcus saprophyticus and Enterococcus. ${ }^{1}$ When Staphylococcus epidermidis is isolated in urine culture, it is assumed to be a contaminant. ${ }^{2}$ As demonstrated in the following case, however, this assumption should not be made in a symptomatic child for whom an alternate source of infection cannot be identified. This case also highlights the importance of suspecting an underlying urinary tract abnormality when S. epidermidis is identified as the causative agent of UTIs in children.

This article was externally peer reviewed.

Submitted 10 April 2014; revised 21 July 2014; accepted 29 July 2014.

From the Department of Community Health and Family Medicine, and the H. James Free Center for Primary Care Education and Innovation, University of Florida College of Medicine, Gainesville, FL (VL, GF, RH); and the Department of Family Medicine, Memorial Hospital of Converse County, Douglas, WY (PLS, SLT).

Funding: none.

Conflict of interest: none declared.

Corresponding author: Valentina Lozano, BS, Department of Community Health and Family Medicine, PO Box 100222, Gainesville, FL 32610 (E-mail: vlozano@ufl.edu).

\section{Case Report}

A previously healthy 4-year-old circumcised boy presented with fever, abdominal pain and vomiting for 1 day. A clean catch urinalysis showed 4 to 6 white blood cells per high-powered field and moderate bacteria. His symptoms continued to worsen; his white blood cell count was 23,900/ $\mathrm{mm}^{3}(83.7 \%$ neutrophils, $9.2 \%$ lymphocytes, $6.5 \%$ monocytes) and his C-reactive protein concentration was $5.8 \mathrm{mg} / \mathrm{dL}$. He was admitted for dehydration and systemic inflammatory response syndrome. Imaging was done to rule out appendicitis and pneumonia.

On hospital day 3, C-reactive protein spiked to $20 \mathrm{mg} / \mathrm{dL}$ and urine culture grew $>100,000$ colonyforming units (CFUs) of $S$. epidermidis/mL. Because of reluctance to ascribe the patient's illness to $S$. epidermidis, the urine culture was repeated and again grew 100,000 CFUs of S. epidermidis/mL. The patient was treated with intravenous levofloxacin $10 \mathrm{mg} / \mathrm{kg}$ twice a day and improved back to his baseline within 12 hours.

The new working diagnosis was sepsis secondary to pyelonephritis, at which point a renal ultrasound was ordered and showed normal kidneys bilaterally; the bladder was incompletely distended but grossly normal. 
Table 1. Case Reports of Previously Healthy Boys Who Had a Urinary Tract Infection Caused by Staphylococcus epidermidis and the Urinary Tract Abnormality Found on Each Case

\begin{tabular}{|c|c|c|c|c|c|c|}
\hline Authors & $\begin{array}{l}\text { Age } \\
\text { (years) }\end{array}$ & Symptoms Reported & Urinalysis (cells/hpf) & $\begin{array}{l}\text { Urine culture } \\
\text { (Staphylococcus } \\
\text { epidermidis growth } \\
\text { in CFUs/mL) }\end{array}$ & $\begin{array}{l}\text { Second } \\
\text { Urine } \\
\text { Culture }\end{array}$ & $\begin{array}{l}\text { Urinary Tract } \\
\text { Abnormality }\end{array}$ \\
\hline \multirow[t]{2}{*}{$\begin{array}{l}\text { Hagler \& } \\
\text { Dobkin }\end{array}$} & 9 & $\begin{array}{l}\text { Dysuria, difficulty } \\
\text { initiating urinary } \\
\text { stream }\end{array}$ & $\begin{array}{l}\text { RBCs } 3-6, W B C s 100, \\
\text { large bacteria }\end{array}$ & $\begin{array}{c}>100,000 \text { and } \\
\text { Enterococcus }\end{array}$ & Same as first & $\begin{array}{l}\text { Diverticulum of the } \\
\text { bladder }\end{array}$ \\
\hline & 11 & $\begin{array}{l}\text { Fever, abdominal pain, } \\
\text { vomiting, sore } \\
\text { throat, diarrhea }\end{array}$ & $\begin{array}{l}\text { WBCs 20-30, large } \\
\text { bacteria }\end{array}$ & $>100,000$ & Same as first & $\begin{array}{l}\text { Diverticulum of the } \\
\text { bladder }\end{array}$ \\
\hline \multirow[t]{2}{*}{$\begin{array}{l}\text { Hall \& } \\
\quad \text { Snitzer }\end{array}$} & 6 & $\begin{array}{l}\text { Fever, abdominal and } \\
\quad \text { flank pain, vomiting }\end{array}$ & $\begin{array}{l}\text { RBCs } 2-4, \text { proteinuria } \\
\quad+1 \text {, ketonuria }+1\end{array}$ & $>1,000,000$ & Same as first & $\begin{array}{l}\text { Bilateral grade III } \\
\text { reflux, bilateral } \\
\text { duplicating } \\
\text { collecting system }\end{array}$ \\
\hline & 7 & $\begin{array}{l}\text { Fever, abdominal pain, } \\
\text { vomiting, chills }\end{array}$ & $\begin{array}{l}\text { RBCs } 0-1, \text { WBCs } 3-5 \text {, } \\
\text { proteinuria }+1 \text {, trace } \\
\text { blood, ketonuria }+2\end{array}$ & $>100,000$ & $>50,000$ & $\begin{array}{l}\text { Right grade III } \\
\text { reflux, left grade } \\
\text { II reflux }\end{array}$ \\
\hline $\begin{array}{l}\text { McDonald } \\
\text { and Lohr }\end{array}$ & 11 & $\begin{array}{l}\text { Fever, abdominal pain, } \\
\text { vomiting, }\end{array}$ & $\begin{array}{l}\text { WBCs 5-8, trace } \\
\text { leukocyte esterase }\end{array}$ & $>100,000$ & Same as first & $\begin{array}{l}\text { Right grade III } \\
\text { reflux }\end{array}$ \\
\hline $\begin{array}{l}\text { Upadhyayula } \\
\text { et } \mathrm{al}^{5}\end{array}$ & $<1$ & $\begin{array}{l}\text { Fever, upper } \\
\text { respiratory } \\
\text { symptoms }\end{array}$ & WBCs $<5$ & $1000-100,000$ & $>100,000$ & $\begin{array}{l}\text { Right grade } V \\
\text { reflux, left grade } \\
\text { IV reflux }\end{array}$ \\
\hline
\end{tabular}

RBC, red blood cell; WBC, white blood cell.

The patient completed a 3-day course of intravenous levofloxacin and was sent home with oral levofloxacin for 12 days. An outpatient vesicocystourethogram was performed and revealed right grade II reflux and no reflux on the left. The patient was referred to urology for follow-up.

\section{Discussion}

S. epidermidis is not generally regarded as the causative agent of UTI in children with no preexisting conditions. This organism has more commonly been associated with UTIs in patients with indwelling urinary catheters and other instrumentation in the urinary tract. ${ }^{3}$ When grown in culture in a healthy patient, S. epidermidis has traditionally been considered a contaminant. This case and 6 others like it (summarized in Table 1) provide evidence that this assumption should be avoided in symptomatic patients.

A PubMed literature search was done using the following terms: Staphylococcus epidermidis, urinary tract infection, healthy, and pyelonephritis and filtered to ages 0 to 18 . Four case reports of $S$. epidermidis UTI were identified and are detailed in Table 1. All cases identified occurred in previously healthy boys, most of whom were circumcised. Most pa- tients presented with gastrointestinal complaints and were incorrectly diagnosed with viral gastroenteritis after exclusion of appendicitis. Although not all patients displayed frank pyuria on urinalysis, in all cases urine cultures grew $>100,000$ CFUs/ $\mathrm{mL}$. All patients were treated with antibiotics and fully recovered within a few days. Of greatest significance, all the children had underlying urinary tract abnormalities, detailed in Table 1, which were identified via renal ultrasound and vesicocystourethogram.

\section{Conclusion}

While S. epidermidis has classically been regarded as a urinary contaminant, caution should be taken before making this assumption. In a symptomatic patient with repeat positive urine cultures, the possibility of an S. epidermidis UTI should be considered as the cause of the patient's symptoms. In addition to treatment with proper antibiotics, further workup for underlying urinary tract abnormalities is essential.

\section{References}

1. Edlin RS, Shapiro DJ, Hersh AL, Copp HL. Antibiotic resistance patterns of outpatient pediatric urinary tract infections. J Urol 2013;190:222-7. 
2. Hagler S, Dobkin D. Urinary tract infection in the male caused by Staphylococcus epidermidis associated with diverticulum of the bladder. Clin Pediatr (Phila) 1990;29:527-8.

3. Hall DE, Snitzer JA 3rd. Staphylococcus epidermidis as a cause of urinary tract infections in children. J Pediatr 1994;124:437-8.
4. McDonald JA, Lohr JA. Staphylococcus epidermidis pyelonephritis in a previously healthy child. Pediatr Infect Dis J 1994;13:1155-6.

5. Upadhyayula S, Kambalapalli M, Asmar BI. Staphylococcus epidermidis urinary tract infection in an infant. Case Rep Infect Dis 2012;2012: 983153. 